Fixed Point Theory, 21(2020), No. 2, 507-524

DOI: $10.24193 /$ fpt-ro.2020.2.37

http://www.math.ubbcluj.ro/ nodeacj/sfptcj.html

\title{
THE SPLIT FIXED POINT PROBLEM FOR DEMICONTRACTIVE MAPPINGS AND APPLICATIONS
}

\author{
ADISAK HANJING* AND SUTHEP SUANTAI** \\ *PhD Degree Program in Mathematics, Faculty of Science, Chiang Mai University \\ Chiang Mai 50200, Thailand \\ E-mail: adisak_h@cmu.ac.th \\ ** Research center in Mathematics and Applied Mathematics, Data Science Research Center, \\ Department of Mathematics, Faculty of Science, Chiang Mai University, Chiang Mai 50200, \\ Thailand \\ E-mail: suthep.s@cmu.ac.th
}

\begin{abstract}
In this paper, we propose a new algorithm to approximate a split common fixed point problem for two demicontractive mappings and prove strong convergence of the proposed method in real Hilbert spaces. As the application, we apply our main results to study the split common null point problem, split variational inequality problem, split convex minimization problem and split equilibrium problem in frame work of real Hilbert spaces. Some numerical example supporting our main result is also given.

Key Words and Phrases: Fixed point problem, minimization problem, variational inequality problem, equilibrium problem, demicontractive mapping.
\end{abstract}

2010 Mathematics Subject Classification: 47H09, 47J05, 47J25, 47H10, 47N10.

Acknowledgement. The authors would like to thank Chiang Mai University, Chiang Mai, Thailand for the financial support.

\section{REFERENCES}

[1] E. Blum, W. Oettli, From optimization and variational inequalities to equilibrium problem, Math Student., 63(1994), 123-145.

[2] C. Byrne, Iterative oblique projection onto convex set and the split feasibility problem, Inverse Probl., 18(2002), 441-453.

[3] A. Cegielski, Iterative Methods for Fixed Point Problems in Hilbert Spaces, Springer, Heidelberg, 2012.

[4] Y. Censor, T. Elfving, A multiprojection algorithm using Bregman projections in a product space, Numer. Algorithms., 8(1994), 221-239.

[5] P.L. Combettes, A. Hirstoaga, Equilibrium programming in Hilbert spaces, J. Nonlinear Convex Anal., 6(2005), 117-136.

[6] P.E. Mainge, Approximation methods for common fixed points of nonexpansive mappings in Hilbert spaces, J. Math. Anal. Appl., 325(2007), 469-479.

[7] G. Marino, H.K. Xu, A general iterative method for nonexpansive mappings in Hilbert spaces, J. Math. Anal. Appl., 318(2006), 43-52. 
[8] A. Moudafi, The split common fixed point problem for demicontractive mappings, Inverse Probl., 26(2010), 587-600.

[9] A. Moudafi, A note on the split common fixed point problem for quasinonexpansive operators, Nonlinear Anal., 74(2011), 4083-4087.

[10] L.J. Qin, L. Wang, S.S. Chang, Multiple set split feasibility problem for a finite family of asymptotically quasi nonexpansive mappings, Panam. Math. J., 22(2012), no. 1, 37-45.

[11] Y. Shehu, New convergence theorems for split common fixed point problems in Hilbert spaces, J. Nonlinear Convex Anal., 16(2015), no. 1, 167-181.

[12] Y. Shehu, P. Cholamjiak, Another look at the split common fixed point problem for demicontractive operators, Rev. Real Acad. Cienc. Exactas Fis. Nat. Ser. A Math. RACSAM., 110(2016), 201-218.

[13] Y. Shehu, F.U. Ogbuisi, An iterative algorithm for approximating a solution of split common fixed point problem for demicontractive maps, Dynamics of Continuous, Discrete and Impulsive Systems Series B: Applications and Algorithms, 23(2016), 205-216.

[14] W. Takahashi, Introduction to Nonlinear and Convex Analysis, Yokohama Publishers, Yokohama, 2009.

[15] S. Takahashi, W. Takahashi, M. Toyoda, Strong convergence theorems for maximal monotone operators with nonlinear mappings in Hilbert spaces, J. Optim. Theory Appl., 147(2010), 27-41.

[16] W. Takahashi, H.K. Xu, J.C. Yao, Iterative methods for generalized split feasibility problems in Hilbert spaces, Set-Valued Var. Anal., 23(2015), 205-221.

[17] F. Wang, H.K. Xu, Approximation curve and strong convergence of the CQ algorithm for the split feasibility problem, J. Inequal. Appl., (2010), DOI: 10.1155/2010/102085.

[18] H.K. Xu, Iterative algorithms for nonlinear operators, J. London Math. Soc., 66(2002), 240-256.

[19] H.K. Xu, A variable Krasnosekel'skill-Mann algorithm and the multiple-set split feasibility problem, Inverse Probl., 22(2006), 2021-2034.

[20] Q. Yang, The relaxed CQ algorithm for solving the split feasibility problem, Inverse Probl., 20(2004), 1261-1266.

Received: January 9, 2018; Accepted: April 18, 2018. 